\title{
ОПЕРНА ВОКАЛЬНА ІНТЕРПРЕТАЦІЯ ЯК ПРЕДМЕТ НАУКОВОГО ДИСКУРСУ
}

\author{
Ігор Борко
}

e-mail: igorborko@rambler.ru; ORCID: 0000-0003-3075-9715

Національна музична академія України імені П. І. Чайковського, Київ, Україна

\section{Анотація}

Художньо-виражальні засоби творення сценічної образності в оперному мистецтві тісно пов'язані зі стилістикою оперного співу виконавця, невід'ємною складовою якого є вокальна інтерпретація. Мета дослідження - проаналізувати сучасний стан наукових досліджень вокальної інтерпретації як невід'ємної складової оперного мистецтва. Методологія дослідження спирається як на загальнонаукові, так і на спеціальні методи дослідження: аналіз - для з'ясування змісту досліджень з проблем оперної вокально-сценічної інтерпретації; історико-генетичний - для розуміння значення вокальної інтерпретації в історії розвитку оперного мистецтва; дедуктивний - спрямував дослідження від узагальненого розуміння теорії оперного жанру до конкретного, зокрема ролі вокальної інтерпретації як складової оперно-виконавського мистецтва; компаративний - для порівняння характеристик вокальної інтерпретаційної стилістики виконавців. Наукова новизна. Ця робота є спробою осягнути науково-аналітичний досвід у царині сценічної оперно-вокальної інтерпретації. Висновки. Вокально-сценічна, образно-творча діяльність оперного співака як виконавця-інтерпретатора вимагає глибокого аналізу та розуміння виконуваного музичного твору в культурно-історичному контексті епохи поруч із високою майстерністю та яскравістю самовираження під час розв'язання комплексу художньовиконавських і технічних завдань. Зважаючи на це, оперний виконавець створює власну інтерпретаційну версію вокального твору, яка має бути різноманітною, але визначеною межами традицій. Інтерпретаційні версії визначаються особливостями донесення змісту художнього тексту, емоційного підтексту оперної партії за допомогою різних комплексів експресивних засобів, прийомів вокальної техніки таступенем занурення в історичний контекст. Чіткість артикуляції та дикція в сукупності з іншими засобами художньої виразності та індивідуальними особливостями звуковидобування визначають оригінальний стиль оперного співака-інтерпретатора. Використання нових і традиційних вокально-інтерпретаційних моделей відкриває широкі можливості для дослідження історико-теоретичного аспекту оперного мистецтва різних періодів, його композиторських шкіл та жанрів. Аналіз наукових досліджень показав, що у них питання оперної вокально-сценічної інтерпретації висвітлювались або дотично, у контексті вивчення інших проблем оперного мистецтва, або на відповідному етапі його історичного розвитку. Наразі перед сучасною науковою думкою постає завдання комплексного осмислення ролі вокальної інтерпретації в процесі створення сценічної образності в оперному мистецтві з визначенням різних вокально-інтерпретаційних 
Вісник Київського національного університету культури і мистецтв.

Серія: Сценічне мистецтво

моделей з урахуванням еволюційних процесів, національних та жанрових особливостей, існування різних виконавських шкіл та творчості окремих виконавців.

Ключові слова: вокальна інтерпретація; оперне мистецтво; виконавський стиль; науковий дискурс

\section{Постановка проблеми}

Опера - художній твір, зміст якого втілюється за допомогою синтетичного поєднання в сценічному творі театральної дії, вокальної та інструментальної музики, драматургії, образотворчого мистецтва, іноді й хореографії за умови домінування музичної складової. Сольний спів у його підпорядкуванні законам театру та в поєднанні із законами музикотворення був як генезою оперного мистецтва, так і джерелом його подальших трансформацій. Магістральними векторами в історії розвитку оперного театру завжди були два напрями - театральний з його тяжінням до сценічної дії в акторському виконанні й епічний з наративно-дискурсійною домінантою. Саме у такій площині варто розглядати роль сольного співу в оперному мистецтві, що становить його провідну семантичну ознаку. Важливе значення в мистецтві сольного оперного співу має вокальна інтерпретація як складова виконавської майстерності.

Поряд з темповими, ритмічними, динамічними й іншими особливостями виконання співочий звук оперного виконавця може виступати самостійним засобом виразності. Грамотне володіння основами техніки bel canto дає змогу оперному співакові змінювати вокальні характеристики свого голосу для виконання музики різних епох і стилів. У цій складній виконавській структурі вокальноінтерпретаційної моделі вокальна техніка є кінцевою ланкою і може бути яскравою та стилістично збалансованою тільки за умови ефективного функціонування всієї системи. Якість співу безпосередньо залежить від вокальної майстерності, рівня підготовки, індивідуальних голосових даних та емоційного стану співака. Крім осмислення змісту і структури твору, оперний співак є творцем сценічного образу свого персонажа. У процесі перевтілення в сценічний образ голосовий апарат виконавця сам інтуїтивно передає пережиті емоції. У такий спосіб образ, створений акторською уявою, спонукає виконавця до застосування відповідної вокальної техніки оперного виконавця-інтерпретатора. Своєю чергою зі зміною тембру, сили голосу, вібрато, через активність артикуляції звуків під час їх продукування наш слух легко розрізняє емоційний стан, в якому знаходиться оперний співак. Навіть якщо виконавець співає іноземною мовою, яку глядач може і не знати, він розуміє, якими почуттями в цей момент сповнений персонаж на сцені. Адже мова музики й емоцій є універсальною та не потребує вербального комунікативного контакту.

\section{Аналіз останніх досліджень і публікацій}

До вивчення проблем інтерпретації, зокрема у виконанні хорової музики, звертались І. Браудо (1973), К. Виноградов (1967), Н. Даньшина (2013), П. Кова- 
лик (2005), І. Кузьмінський (2014), В. Москаленко (2012; 1994). Принципи стилістики сценічно-виконавської інтерпретації у бароковій музиці проаналізовано в роботах Ж.-К. Вейлан (Veilhan, 1975), О. Круглової (2007), Н. Сікорської (2015), Р. Стельмащук (2011), О. Фоміна (2013).

Вивченню композиторського стилю В. Кирейка як інтерпретатора «глибоких національних та класико-романтичних традицій української академічної музики», у творчості якого «органічно синтезуються національні та європейські здобутки», присвячена публікація І. Шестеренко (2013, с.169). Зокрема особливості інтерпретації в оперній творчості В. Кирейко досліджує І. Шестеренко у статті «Оперна творчість українського композитора Віталія Кирейка» - композитор $€$ автором драми-феєрії «Лісова пісня», романтичної драми «У неділю рано», гротесково-сатиричної феєрії «Марко в пеклі», камерної комічної опери «Вернісаж на ярмарку», опери-драми «Бояриня» (Shesterenko, 2020, pp.65-68).

Водночас досі в названих дослідженнях предметно не розглядали оперну вокальну інтерпретацію як предмет наукового дискурсу. Отже, актуальність теми дослідження обумовлена необхідністю подальшоїпоглибленоїрозробки науковотеоретичного аспекту вокальної інтерпретації в практиці оперного мистецтва.

Мета роботи - проаналізувати сучасний стан наукових досліджень вокальної інтерпретації як невід'ємної складової оперного мистецтва.

\section{Виклад основного матеріалу}

Проблеми вокально-виконавської інтерпретації систематично висвітлюють в роботах, присвячених діяльності окремих видатних співаків і вокальних педагогів у безпосередньому зв'язку з їхньою творчістю. Важливість подібних публікацій для вивчення вокального виконавства важко переоцінити з точки зору узагальнення досвіду виконавської практики й тісно пов'язаної з нею практики педагогічної. Здебільшого мова в них йде про індивідуальний виконавський стиль того чи іншого співака (Дмитриев, 1984, с.135-156).

У цьому ракурсі великий інтерес представляє книга відомого італійського оперного співака Джакомо Лаурі-Вольпі «Voci parallele» («Вокальні паралелі»). Спираючись на свій багатий сценічний досвід, автор розглядає індивідуальні особливості артистичного вигляду понад 150 співаків, порівнює вокальні школи Італії та Франції; аналізує переваги та недоліки в методах емісії звуку, розкриває тонкощі ставлення окремих співаків до поетичного тексту (Lauri-Volpi, 1955).

Найважливіші питання проголошення поетичного тексту в співі, включаючи такі моменти, як дикційна чіткість, художня виразність, відповідність правилам орфоепії, нюанси саме вокальної орфоепії, неодноразово порушувалися в роботах Є. Є. Нестеренко (1985).

Набагато частіше, ніж в науковій літературі, стилістичні проблеми вокального виконання розглядають у процесі живого спілкування початківців-співаків з майстрами вокального мистецтва. Ось чому таку цінність мають записи майстер-класів Марії Каллас в Джульярдській школі музики (Нью-Йорк, 11 жовтня - 18 листопада 1971 року, 7 лютого - 16 березня 1972 року). Співачка розкриває тонкощі використання вокально-виконавських прийомів (атака 
Вісник Київського національного університету культури і мистецтв.

Серія: Сценічне мистецтво

звуку, різні способи з'єднання вокальних тонів, динамічні градації, імпровізація каденцій) у тісному зв'язку зі створенням художнього образу в застосуванні до різних в музично-стилістичному відношенні творів (арії з опер та ораторій В. Белліні, Г. Берліоза, Л. ван Бетховена, Ж. Бізе, Дж. Верді, Ш. Гуно, Д. Дж. Доніцетті, Л. Керубіні, П. Масканьї, Ж. Массне, В. А. Моцарта, А. Понк'єллі, Дж. Пуччіні, Дж. Россіні) (Дмитриев, 1984, с.135-156).

Сучасна оперна педагогічна практика виявляє серйозні недоліки в професійній підготовці вокалістів для інтерпретації творів різних епох. Тут можна позначити дві основні проблеми. Перша пов'язана з тим, що робота сучасного виконавця, зокрема в Україні, з оперним музичним текстом зводиться в основному до технічного розбору вокальної партії. У педагогічній практиці $є$ набір прийомів освоєння нотного тексту, який являє собою вироблений стереотип роботи, що зорієнтований переважно на технологічні прийоми. Крім того, у системі вітчизняної вокальної освіти не передбачена спеціальна підготовка у сфері сучасного українського виконавства. Тому виконавці переважно звертаються до музичних творів XVIII-XX століть, що виконуються здебільшого в романтичних традиціях, під впливом яких сформована сучасна вокальна академічна школа. Наприклад, для виконання італійської опери XIX століття, вершиною розвитку якої стала вердіївська драма, співаку потрібно володіти голосом значної сили, потужності, барвистості звуку, особливо у верхньому регістрі, на який лягає основне навантаження в кульмінаційні моменти не лише в арії, але і в речитативі. Ту ж вокальну техніку педагоги та вокалісти опери зазвичай екстраполюють під час автентичного виконання творів старих майстрів.

Такий підхід є стилістично недостовірним. У результаті вокальна інтерпретація стає безликою та невиразною. Одну з причин такого становища вбачаємо в тому, що є вкрай мало досліджень у сфері теорії і практики оперного виконавства, науково-методичних розробок, які могли б скласти об'єктивну методологічну основу вивчення сучасної вокальної інтерпретації опери, зокрема української.

Вокально-сценічна передача афекту оперного виконавця-інтерпретатора вимагає від співака осягнення музичного твору в культурно-історичному контексті, широти та яскравості самовираження під час розв'язання цілого комплексу художньо-виконавських і технічних завдань. На цій основі вокаліст, оперний виконавець створює власну інтерпретаційну версію вокального твору, яка може бути різноманітною, але обмеженою традиціями. Інтерпретаційні версії визначаються особливостями донесення змісту художнього тексту, емоційного підтексту оперної партії за допомогою різних комплексів експресивних засобів, прийомів вокальної техніки, різним ступенем занурення в історичний контекст. Чіткість і виразність артикуляції в сукупності з іншими прийомами вокального звуковидобування визначають виконавський стиль оперного виконавцяінтерпретатора.

Проблеми, пов'язані з рівнем вокального оперного виконавства, можуть ефективно розв'язуватися тільки з урахуванням усіх складових в їх взаємозв'язку. На цій основі стає можливою послідовна та цілеспрямована праця над вокальною партією. Під час виникнення проблеми легко визначити, на яку 
Bulletin of Kyiv National University of Culture and Arts

Series in Stage Art

складову потрібно звернути особливу увагу та вичленувати ії для більш детального опрацювання. Зокрема, вокальна дикція як компонент, який має складну структуру, вимагає особливої уваги та спеціальної методики, пов'язаної з окремими вправами для зміцнення апарату артикуляції, з вправами, спрямованими на освоєння вокальної фонетики мови виконуваного твору, з роботою над вокальною орфоепією, над окремими смисловими словами і художнім текстом в цілому.

У загальнофілософському розумінні поняття «інтерпретація» (лат. interpretatio - тлумачення, роз'яснення, розкриття змісту, трактування) належить до гносеологічної категорії як спосіб сприйняття, тлумачення і відображення дійсності з кореляцією щодо різних видів мистецтв. 3 огляду на широту та універсальність поняття його використовують у різних площинах, зокрема в мистецтві. Щодо художньої інтерпретації, інтерпретації у творах мистецтва тут ключовим $є$ розуміння цілісності активного самовиявлення особи митця в процесі творення, прояву його особистісно-індивідуалізованого ставлення до акту творення.

Інтерпретація у музичному мистецтві $€$ одним з різновидів художньої інтерпретації, де в процесі публічного виконання твору здійснюється акт авторського прочитання музичного твору вокально-інструментальними засобами виразності для розкриття його ідейно-образного змісту. 3 огляду на вторинність (після авторської композиторської) музична інтерпретація немислима без виконавської, певною мірою «посередницької», де інтерпретатор-виконавець має бути наділений як особистим світоглядом, так і творчою здібністю (талантом), професійною майстерністю, що підкріплюється власним художньовиконавським методом. І. М. Ямпольський наголошує, що імпровізація в музиці «залежить від естетичних принципів школи або напряму, до яких належить артист, від його індивідуальних особливостей і ідейно-мистецького задуму. Інтерпретація передбачає індивідуальний підхід до виконуваної музики, активне до неї ставлення, наявність у виконавця власної творчої концепції втілення авторського задуму» (Ямпольский, 1974). Такий підхід поширюється на музику як в інструментальному, так і у вокальному виконанні, зокрема оперному.

Звертаючись до вивчення проблем психології музичної творчості, Л. Бочкарьов розглядає поняття інтерпретації як різновиду художньої творчості, що об'єднує індивідуальні естетичні вподобання виконавця, його навички та майстерність, набутий виконавський стиль, які корелюються з авторською композиторською інтерпретацією, що відображена у творі (Бочкарев, 1997). Отже, з точки зору розуміння психології музичної діяльності виконавець твору має спершу осмислити шлях музикотворення, яким пройшов композитор, усвідомити музично-предметний ряд твору та, осягнувши його як цілісну форму, у процесі сценічного виконання надати нового естетичного значення, якого немає в об'єктивно-звукових характеристиках.

І. Є. Герсамія, зосереджуючи фокус свого дослідження на проблемах психології творчості співака та методах тестування його професійної придатності, констатує, що інтерпретація вокального твору наявна у двох головних аспектах об'єктивному та суб'єктивному. Об'єктивний - охоплює всю інформацію, яка 
Вісник Київського національного університету культури і мистецтв.

Серія: Сценічне мистецтво

з достатньою достовірністю розкриває зміст твору, втіленого в літературному та нотному текстах, а також у наявних в ньому ремарках, що уточнюють характер виконання. Суб'єктивний аспект передбачає прояв особистісного ставлення виконавця до об'єктивних даних про композиторські задуми й створення на цій основі власного трактування твору (Герсамия, 1985).

Об'єктивний аспект передбачає реалізацію вокальної інтерпретації в естетичному, культурно-історичному та стильовому контекстах. У роботах з музичної естетики як вектора музикознавства (Асафьев, 1965; Маркус, 1959, 1968; Рыжкин, 1967) описано особливості чуттєво-образного сприйняття музики виконавцями і слухачами оперного мистецтва, що пов'язані з особливостями та закономірностями музичної лексики в різні епохи, манерою виконання.

До аналізу історичних етапів (від II тисячоліття до н. е. до сучасності) вокального виконавства як наукової дисципліни й окремого різновиду мистецтва в музичній європейській культурі звертається О. Г. Стахевич. Особливу увагу автор звертає на проблему формування стилів сольного співу у вокально-виконавській практиці оперного мистецтва різних епох - бароко, класицизму, романтизму та інших. За О. Г. Стахевичем $(2013$, с.7) в опері «еволюція мистецтва співу - це еволюція вокально-виконавських стилів, кожний з яких ґрунтується на власній теорії». Автор трактує поняття «стиль» як комплекс характеристик як мистецького напряму епохи, так і певної національної школи чи окремої творчої особистості, виконавця, наприклад Марії Каллас - «індивідуальний стиль художника, якість художнього твору, музично-виконавську інтерпретацію» (Стахевич, 2013, с.6).

Для музикознавчого розуміння специфіки вокальної оперної інтерпретації в історичному контексті Н. А. Мятієва пропонує вживати термін «текстуальна стратегія» як «історично детермінований метод кодування композитором музичної інформації та подальше декодування створеного письмового тексту виконавцем» (Мятиева, 2010, с.65). Авторка пропонує розподіл текстуальної стратегії на три категорії: старовинну, класико-романтичну та новітню, для якої, зокрема, характерний різний підхід до розуміння композиторської та виконавчої інтерпретації.

Фундаментальною роботою, в якій цілісно розглянуто питання еволюції української вокальної школи, є дослідження Б. Гнидя «Історія вокального мистецтва». Звертаючись до компаративного підходу в оцінці провідних західноєвропейських вокальних шкіл - італійської, французької, німецької та до аналізу їх впливу на українську школу, автор наголошує на унікальності вокальносценічного інтерпретаційного підходу кожної з них. Автор стверджує:

«Національний характер вокальних шкіл обумовлений складом життя кожного народу: його поезією, законами фонетики мови, народними традиціями в музиці, мистецтвом народних співаків. Ця своєрідність проявляється у змісті, жанрах, звуковеденні, емоційності, використанні регістрів голосу, ролі слова в музиці, ритміці, ладовій структурі, мелізматиці. [...] Звучання італійських співаків завжди істотно відрізнялось від інструментального («прямого») звучання німецького вокаліста, від французького співака з його декламаційним характером звучання». (Гнидь, 1997. с.4) 
До вивчення особливостей української вокальної школи, зокрема інтерпретаційної традиції українських співаків, Б. Гнидь (1999, с.7-17) звертається також у подальших своїх роботах.

У виявлених сучасних вітчизняних наукових дослідженнях простежуються тенденції виконавської інтерпретації оперних творів у певний культурно-історичний період з огляду на різні виконавські оперні практики. Зокрема, А. А. Лісогорська (2020) звертається до вивчення досвіду втілення на сцені жіночих образів в операх П. І. Чайковського у контексті специфіки їх виконавської та режисерської музично-сценічних інтерпретацій, систематизує досвід виконання головних партій в операх композитора, акцентуючи на вокальній інтерпретації С. Крушельницької, та простежує загальні тенденції в еволюції сценічно-виконавського трактування жіночих образів у перших прижиттєвих і подальших постановках.

М. О. Марченко (2021) предметно звертається до вивчення інтерпретаційної моделі партесних творів у контексті культури виконання барокової музики на межі XX-XXI ст. Звертаючись до вивчення виконавської традиції в українській опері конкретного історичного періоду, авторка наголошує, що міра інтерпретації сценічно-вокальної інтерпретації залежить від глибини занурення оперного виконавця в історичний контекст епохи, втілюється індивідуальними засобами виразності, що передбачають кілька взаємопов'язаних компонентів: вокальну дикцію, акторську майстерність виконавця, музичні засоби виразності, вокальну техніку. Кожен з них має бути так чи інакше універсальним для реалізації історичного підходу до вокально-оперної інтерпретації.

А. П. Шило, зважаючи на аналіз творчого доробку української оперної співачки Л. А. Руденко, розглядає проблему музично-виконавської інтерпретації сценічного образу в оперному мистецтві. Працюючи над оперними партіями, Л. А. Руденко прагнула «розкрити не тільки образ, а й саму епоху, в якій діяла її героїня». Водночас їй була

«доступна передача типових рис характеру та емоційного стану не тільки жінки-слов'янки, а й інших національностей (італійки, француженки, циганки), а також жінок різних соціальних прошарків від аристократок до авантюристок. [...] У своїй роботі над оперними партіями вона ставила завдання створити реалістичний, життєвий образ жінки, сповнений енергії і почуттів. Саме це висунуло її у перші лави виконавиць партій мецо-сопрано світового рівня». (Шило, 2020, с. 106)

О. Г. Небога зосереджує свою дослідницьку увагу на вивченні стильових рис в академічному сольному співі, що характеризують київську вокальну школу як складову української вокальної культури. Авторка простежує шлях історичної еволюції київської школи академічного співу та розширює розуміння специфіки вокальної інтерпретації в сучасній оперній музиці, зокрема звертаючись до аналізу особливостей виконавської майстерності Є. Мірошниченко, Д. Гнатюка, М. Кондратюка та А. Кочерги (Небога, 2021).

Зважаючи на аналіз історіографії в контексті вивчення особливостей оперної вокальної інтерпретації як складової сценічної образотворчості, можна стверджувати, що цей музично-театрознавчий аспект потребує предметного поглибленого наукового вивчення. 
Вісник Київського національного університету культури і мистецтв.

Серія: Сценічне мистецтво

Наукова новизна. Ця робота $є$ спробою осягнути науково-аналітичний досвід у царині сценічної оперно-вокальної інтерпретації.

\section{Висновки}

Вокально-сценічна, образно-творча діяльність оперного співака як виконавця-інтерпретатора вимагає як глибокого аналізу та розуміння виконуваного музичного твору в культурно-історичному контексті епохи, так і високої майстерності та яскравості самовираження під час розв'язання комплексу художньо-виконавських і технічних завдань. 3 огляду на це оперний виконавець створює власну інтерпретаційну версію вокального твору, яка має бути різноманітною, але визначеною межами традицій. Інтерпретаційні версії визначаються особливостями донесення змісту художнього тексту, емоційного підтексту оперної партії за допомогою різних комплексів експресивних засобів, прийомів вокальної техніки та ступенем занурення в історичний контекст. Чіткість артикуляції та дикція в сукупності з іншими засобами художньої виразності та індивідуальними особливостями звуковидобування визначають оригінальний стиль оперного співака-інтерпретатора. Використання нових і традиційних вокально-інтерпретаційних моделей відкриває широкі можливості як для дослідження історико-теоретичного аспекту оперного мистецтва різних періодів, так і його композиторських шкіл та жанрів.

Аналіз наукових досліджень показав, що в них питання оперної вокальносценічної інтерпретації висвітлювались або дотично, у контексті вивчення інших проблем оперного мистецтва, або на відповідному етапі його історичного розвитку. Наразі перед сучасною науковою думкою постає завдання комплексного осмислення ролі вокальної інтерпретації в процесі створення сценічної образності в оперному мистецтві з визначенням різних вокальноінтерпретаційних моделей з урахуванням еволюційних процесів, національних і жанрових особливостей, існування різних виконавських шкіл та творчості окремих виконавців.

\section{СПИСОК ПОСИЛАНЬ}

Асафьев, Б., 1965. Избранные статьи о музыкальном просвещении и образовании. Москва: Музыка.

Бочкарев, Л.П., 1997. Психология музыкальной деятельности. Москва: Институт психологии РАН.

Браудо, И., 1973. Артикуляция (о произношении мелодии). 2-е изд. Ленинград: Музыка. Виноградов, К., 1967. Работа над дикцией в хоре. Москва: Музыка.

Герсамия, И.Е., 1985. К проблеме психологии творчества певца. Тбилиси: Мецниереба.

Гнидь, Б.П., 1997. Історія вокального мистецтва. Київ: Національна музична академія України імені П.І. Чайковського.

Гнидь, Б.П., 1999. Українська вокальна школа в контексті світового виконавського мистецтва. Науковий вісник Національної музичної академії України імені П.І. Чайковського, 2, c.7-17. 
Даньшина,Н., 2013. Специфіка виконання ренесансної вокальної музики в умовах вітчизняної хорової практики. Дисертація кандидата мистецтвознавства. Національна музична академія України імені П.І. Чайковського.

Дмитриев, Л.Б., 1984. Интуиция и сознание в творчестве и вокальной педагогике. Вопросы вокальной педагогики, 7, с.135-156.

Ковалик, П., 2005. Виконавські проекції як ефективна форма підготовки диригентівхормейстерів. Науковий вісник Національної музичної академії України імені П. І. Чайковського, 47, с.153-161.

Круглова, Е., 2007. Традиции барочного вокального искусства и современное исполнительство: на примере сочинений Г.Ф.Генделя. Диссертация кандидата искусствоведения. Российская академия музыки имени Гнесиных.

Кузьмінській,І., 2014. Витоки, музична теорія та виконавська практика партесного багатоголосся. Дисертація кандидата мистецтвознавства. Національна музична академія України імені П.І. Чайковського.

Лісогорська, А.А., 2020. Вокально-сценічна інтерпретація жіночих образів у постановках опер Петра Чайковського. Автореферат кандидата мистецтвознавства. Львівська національна музична академія імені М.В. Лисенка.

Маркус, С.А., 1959. История музыкальной эстетики. Т. 1: С середины XVIII до начала XIX века. Москва: Государственное музыкальное издательство.

Маркус, С.А., 1968. История музыкальной эстетики. Т. 2: Романтизм и борьба эстетических направлений. Москва: Музыка.

Марченко, М.О., 2021. Інтерпретаційна модель партесного твору в українській виконавській культурі на межі XX-XXI cт. Дисертація кандидата мистецтвознавства. Національна музична академія України імені П.І. Чайковського.

Москаленко, В., 1994. Теоретичний та методичний аспекти музичної інтерпретації. Автореферат доктора мистецтвознавства. Київська державна консерваторія імені П. Чайковського.

Москаленко, В., 2012. Лекции по музыкальной интерпретации. Киев: Клякса.

Мятиева, Н., 2010. Исполнительская интерпретация музыки второй половины XX века : вопросы теории и практики. Дисертация кандидата искусствоведения. Магнитогорская государственная консерватория (академия) имени М.И. Глинки.

Небога, О.Г., 2021. Київська вокальна школа в контексті національних культурних традицій. Дисертація кандидата мистецтвознавства. Київський національний університет культури і мистецтв.

Нестеренко, Е.Е., 1985. Размышления о профессии. Москва: Искусство.

Рыжкин, И.Я., 1967. Советское теоретическое музыкознание (1917-1941). Вопросы теории и эстетики музыки, 6-7, с.147-163.

Сикорская, Н., 2015. Принципы эдиционныХ техник второй половины XIX века в особом типе редакций клавирной музыки барокко. Мистецтвознавчі записки, 27, с.41-57.

Стахевич, О.Г., 2013. 3 історії вокально-виконавських стилів та вокальної педагогіки. Вінниця: Нова книга.

Стельмащук, Р., 2011. Барокові музично-риторичні фігури в українській музиці партесного стилю: тенденції, закономірності, особливості. Молодь і ринок, 10, с.100-104.

Фомина, В., 2013. Проблемы современной вокальной интерпретации итальянской оперы первой половины XVII века: на примере опер Клаудио Монтеверди. Диссертация 
кандидата искусствоведения. Саратовская государственная консерватория (академии) им. Л.В. Собинова.

Фомина, В.П., 2014. Стилистические принципы итальянской оперы первой половины XVII века в культурно-историческом контексте. Музыковедение, 3, с.3-8.

Шестеренко, І., 2013. Постать Віталія Кирейка в історії української музики. Національна спілка композиторів України: історія та сучасність, [online] 86, c.168-182. Доступно: <http:// docplayer.net/73234795-Postat-vitaliya-kireyka.html> [Дата звернення 15 травня 2021].

Шило, А., 2020. Музично-виконавська інтерпретація вокальних образів у творчості Лариси Руденко. КОГОГ. Мистецтво наукової думки, 10, с.104-106. https://doi. org/10.36074/2617-7064.10.020.

Ямпольский, И.М., 1974. Интерпретация. В: Ю.В. Келдыша, ред. Музыкальная энциклопедия. Москва: Советская энциклопедия. Т. 2.

Lauri-Volpi, G., 1955. Voci parallele. Milano: Garzanti.

Shesterenko, I., 2020. The Opera Creativity of the Ukrainian composer Vitaliy Kyreyko. Science, Research, Development, [online] 28, pp.65-68. Avialable at: <http://xn--e1aajfpcds8ay4h.com. ua/pages/view/1327> [Accessed 10 April 2021].

Veilhan, J.-C., 1975. The Rules of Musical Interpretation in the Baroque Era (17th-18th centuries) common to all instruments. Translated by J. Lambert. Paris: A. Leduc.

\section{REFERENCES}

Asafev, B., 1965. Izbrannye stati o muzykalnom prosveshchenii i obrazovanii [Selected articles on musical enlightenment and education]. Moscow: Muzyka.

Bochkarev, L.P., 1997. Psikhologiia muzykalnoi deiatelnosti [Psychology of musical activity]. Moscow: Institut psikhologii RAN.

Braudo, I., 1973. Artikuliatciia (o proiznoshenii melodii) [Articulation (on the pronunciation of a melody)]. 2nd ed. Leningrad: Muzyka.

Vinogradov, K., 1967. Rabota nad diktciei v khore [Working on diction in the choir]. Moscow: Muzyka.

Gersamiia, I.E., 1985. K probleme psikhologii tvorchestva pevtca [On the problem of the psychology of the singer's creativity]. Tbilisi: Metcniereba.

Hnyd, B.P., 1997. Istoriia vokalnoho mystetstva [History of vocal art]. Kyiv: Ukrainian National Tchaikovsky Academy of Music.

Hnyd, B.P., 1999. Ukrainska vokalna shkola v konteksti svitovoho vykonavskoho mystetstva [Ukrainian vocal school in the context of world performing arts]. Scientific herald of Tchaikovsky National music academy of Ukraine, 2, pp.7-17.

Danshyna, N., 2013. Spetsyfika vykonannia renesansnoi vokalnoi muzyky v umovakh vitchyznianoi khorovoi praktyky [The specifics of the performance of Renaissance vocal music in the context of domestic choral practice]. PhD Dissertation. Ukrainian National Tchaikovsky Academy of Music.

Dmitriev, L.B., 1984. Intuitciia i soznanie v tvorchestve i vokalnoi pedagogike [Intuition and consciousness in creativity and vocal pedagogy]. Voprosy vokalnoi pedagogiki, 7, pp.135-156.

Kovalyk, P., 2005. Vykonavski proektsii yak efektyvna forma pidhotovky dyryhentiv-khormeisteriv [Performing projections as an effective form of training of choir conductors]. Scientific herald of Tchaikovsky National music academy of Ukraine, 47, pp.153-161. 
Kruglova, E., 2007. Traditcii barochnogo vokalnogo iskusstva $i$ sovremennoe ispolnitelstvo: na primere sochinenii G.F. Gendelia [Traditions of baroque vocal art and contemporary performance: on the example of the works of G.F. Handel]. PhD Dissertation. Rossiiskaia akademiia muzyki imeni Gnesinykh.

Kuzminskii, I., 2014. Vytoky, muzychna teoriia ta vykonavska praktyka partesnoho bahatoholossia [Origins, music theory and performance practice of party polyphony]. PhD Dissertation. Ukrainian National Tchaikovsky Academy of Music.

Lisohorska, A.A., 2020. Vokalno-stsenichna interpretatsiia zhinochykh obraziv u postanovkakh oper Petra Chaikovskoho [Vocal and stage interpretation of female images in productions of operas by Peter Tchaikovsky]. Abstract of PhD Dissertation. Lvivska natsionalna muzychna akademiia imeni M.V. Lysenka.

Markus, S.A., 1959. Istoriia muzykalnoi estetiki [History of musical aesthetics]. Vol. 1: S serediny $X V I I I$ do nachala XIX veka [From the middle of the XVIII to the beginning of the XIX century]. Moscow: Gosudarstvennoe muzykalnoe izdatelstvo.

Markus, S.A., 1968. Istoriia muzykalnoi estetiki [History of musical aesthetics]. Vol. 2: Romantizm i borba esteticheskikh napravlenii [Romanticism and the struggle of aesthetic directions]. Moscow: Muzyka.

Marchenko, M.O., 2021. Interpretatsiina model partesnoho tvoru v ukrainskii vykonavskii kulturi na mezhi $X X-X X I$ st. [Interpretive model of party work in the Ukrainian performing culture at the turn of the $20^{\text {th }}-21^{\text {st }}$ centuries]. PhD Dissertation. Ukrainian National Tchaikovsky Academy of Music.

Moskalenko, V., 1994. Teoretychnyi ta metodychnyi aspekty muzychnoi interpretatsii [Theoretical and methodical aspects of musical interpretation]. Abstract of PhD Dissertation. Kyivska derzhavna konservatoriia imeni P. Chaikovskoho.

Moskalenko, V., 2012. Lektcii po muzykalnoi interpretatcii [Lectures on Musical Interpretation]. Kyiv: Kliaksa.

Miatieva, N., 2010. Ispolnitelskaia interpretatciia muzyki vtoroi poloviny XX veka : voprosy teorii i praktiki [Performing interpretation of music of the second half of the 20th century: questions of theory and practice]. PhD Dissertation. Magnitogorskaia gosudarstvennaia konservatoriia (akademiia) imeni M.I. Glinki.

Neboha, O.H., 2021. Kyivska vokalna shkola v konteksti natsionalnykh kulturnykh tradytsii [Kyiv vocal school in the context of national cultural traditions]. PhD Dissertation. Kyiv National University of Culture and Arts.

Nesterenko, E.E., 1985. Razmyshleniia o professii [Reflections on the profession]. Moscow: Iskusstvo.

Ryzhkin, I.la., 1967. Sovetskoe teoreticheskoe muzykoznanie (1917-1941) [Soviet theoretical musicology (1917-1941)]. Voprosy teorii i estetiki muzyki, 6-7, pp.147-163.

Sikorskaia, N., 2015. Printcipy editcionnykh tekhnik vtoroi poloviny XIX veka v osobom tipe redaktcii klavirnoi muzyki barokko [Principles of traditional techniques of the second half of the 19th century in a special type of editions of baroque clavier music]. Mystetstvoznavchi zapysky, 27, pp.41-57.

Stakhevych, O.H., 2013. Z istorii vokalno-vykonavskykh styliv ta vokalnoi pedahohiky [From the history of vocal-performing styles and vocal pedagogy]. Vinnytsia: Nova knyha.

Stelmashchuk, R., 2011. Barokovi muzychno-rytorychni fihury v ukrainskii muzytsi partesnoho styliu: tendentsii, zakonomirnosti, osoblyvosti [Baroque musical and rhetorical 
figures in Ukrainian music of the Parthian style: trends, patterns, features]. Molod i rynok, 10, pp.100-104.

Fomina, V., 2013. Problemy sovremennoi vokalnoi interpretatcii italianskoi opery pervoi poloviny XVII veka: na primere oper Klaudio Monteverdi [Problems of Modern Vocal Interpretation of Italian Opera of the First Half of the 17th Century: the Case of Claudio Monteverdi's Operas]. PhD Dissertation. Saratovskaia gosudarstvennaia konservatoriia (akademii) im. L.V. Sobinova. Fomina, V.P., 2014. Stilisticheskie printcipy italianskoi opery pervoi poloviny XVII veka $v$ kulturno-istoricheskom kontekste [Stylistic principles of Italian opera of the first half of the 17th century in a cultural and historical context]. Muzykovedenie, 3, pp.3-8.

Shesterenko, I., 2013. Postat Vitaliia Kyreika v istorii ukrainskoi muzyky [The figure of Vitaly Kireiko in the history of Ukrainian music]. Natsionalna spilka kompozytoriv Ukrainy: istoriia ta suchasnist, [online] 86, pp.168-182. Avialable at: <http://docplayer.net/73234795-Postatvitaliya-kireyka.html> [Accessed 15 May 2021].

Shylo, A., 2020. Muzychno-vykonavska interpretatsiia vokalnykh obraziv u tvorchosti Larysy Rudenko [Musical-performing interpretation of vocal images in the works of Larysa Rudenko].

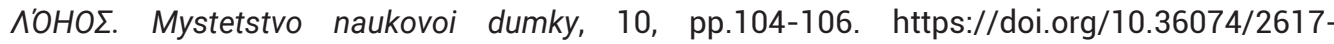
7064.10.020.

lampolskii, I.M., 1974. Interpretatciia [Interpretation]. In: lu.V. Keldysha, ed. Muzykalnaia entciklopediia [Musical encyclopedia]. Moscow: Sovetskaia entciklopediia. Ch. 2.

Lauri-Volpi, G., 1955. Voci parallele. Milano: Garzanti.

Shesterenko, I., 2020. The Opera Creativity of the Ukrainian composer Vitaliy Kyreyko. Science, Research, Development, [online] 28, pp.65-68. Avialable at: <http://xn--e1aajfpcds8ay4h.com. ua/pages/view/1327> [Accessed 10 April 2021].

Veilhan, J.-C., 1975. The Rules of Musical Interpretation in the Baroque Era (17th-18th centuries) common to all instruments. Translated by J. Lambert. Paris: A. Leduc.

\title{
ОПЕРНАЯ ВОКАЛЬНАЯ ИНТЕРПРЕТАЦИЯ КАК ПРЕДМЕТ НАУЧНОГО ДИСКУРСА
}

\section{Игорь Борко}

e-mail: igorborko@rambler.ru; ORCID: 0000-0003-3075-9715

Национальная музыкальная академия Украины имени П. И. Чайковского, Киев, Украина

\begin{abstract}
Аннотация
Художественно-выразительные средства создания сценической образности в оперном искусстве тесно связаны со стилистикой оперного пения исполнителя, неотъемлемой составляющей которого является вокальная интерпретация. Цель исследования проанализировать современное состояние научных исследований вокальной интерпретации как неотъемлемой составляющей оперного искусства. Методология исследования опирается как на общенаучные, так и на специальные методы исследования: анализ - для выяснения содержания исследований по проблемам оперной вокально-сценической интерпретации; историко-генетический - для
\end{abstract}


понимания значения вокальной интерпретации в истории развития оперного искусства; дедуктивный - направил исследования от обобщенного понимания теории оперного жанра к конкретному, в частности роли вокальной интерпретации как составляющей оперно-исполнительского искусства; компаративный - для сравнения характеристик вокальной интерпретационной стилистики исполнителей. Научная новизна. Данная работа является попыткой постичь научно-аналитический опыт в области сценической оперно-вокальной интерпретации. Выводы. Вокально-сценическая, образнотворческая деятельность оперного певца как исполнителя-интерпретатора требует глубокого анализа и понимания выполняемого им музыкального произведения в культурно-историческом контексте эпохи рядом с высоким мастерством и яркостью самовыражения при решении комплекса художественно-исполнительских и технических задач. Исходя из этого оперный исполнитель создает собственную интерпретационную версию вокального произведения, которая должна быть разнообразной, но определенной пределами традиций. Интерпретационные версии определяются особенностями донесения содержания художественного текста, эмоционального подтекста оперной партии с помощью различных комплексов экспрессивных средств, приемов вокальной техники и степенью погружения в исторический контекст. Четкость артикуляции и дикция в совокупности с другими средствами художественной выразительности и индивидуальными особенностями звукоизвлечения определяют оригинальный стиль оперного певца-интерпретатора. Использование новых и традиционных вокально-интерпретационных моделей открывает широкие возможности для исследования историко-теоретического аспекта оперного искусства разных периодов его композиторских школ и жанров. Анализ научных исследований показал, что в них вопросы оперной вокально-сценической интерпретации изложены или косвенно, в контексте изучения других проблем оперного искусства, или на соответствующем этапе его исторического развития. Сейчас перед современной научной мыслью стоит задача комплексного осмысления роли вокальной интерпретации в процессе создания сценической образности в оперном искусстве с определением различных вокальноинтерпретационных моделей с учетом эволюционных процессов, национальных и жанровых особенностей, существования различных исполнительских школ и творчества отдельных исполнителей.

Ключевые слова: вокальная интерпретация; оперное искусство; исполнительский стиль; научный дискурс 


\title{
OPERA VOCAL INTERPRETATION AS A SUBJECT OF SCIENTIFIC DISCOURSE
}

\section{Ihor Borko}

e-mail: igorborko@rambler.ru; ORCID: 0000-0003-3075-9715

Ukrainian National Tchaikovsky Academy of Music, Kyiv, Ukraine

\begin{abstract}
Artistic and expressive means of creating stage imagery in the opera are closely related to the performer's opera singing style, an integral component of which is vocal interpretation. The purpose of the article is to analyse the current state of scientific research on vocal interpretation as an integral component of the opera. The research methodology is based on both general scientific and special research methods. An analysis is to clarify the content of research on the opera vocal-stage interpretation issues; the historical-genetic method is to understand the meaning of vocal interpretation in the history of the opera development; the deductive method has directed research from a generalised understanding of the theory of opera genre to a specific one, in particular, the role of vocal interpretation as a component of the opera and performing arts; the comparative approach is to compare the characteristics of the performers' vocal interpretive style. Scientific novelty. This article is an attempt to comprehend scientific and analytical experience in the field of stage opera and vocal interpretation. Conclusions. Vocal and performing, the imaginative and creative activity of an opera singer as an interpreter requires a deep analysis and understanding of the performed music in the cultural and historical context of the era, along with high skill and brightness of self-expression coping a complex of artistic, performing and technical tasks. As a result, opera performer creates their own interpretation system a version of a vocal piece that should be diverse but defined by the boundaries of tradition. Interpretive versions are determined by the peculiarities of conveying the content of the literary text, the emotional subtext of the opera part through various complexes of expressive means, vocal techniques, and the degree of immersion in the historical context. Clarity of articulation and diction, together with other means of artistic expression and individual features of sound extraction, determine the original style of the opera singer-interpreter. Using new ones and traditional vocal and interpretive models opens up vast opportunities to study opera's historical and theoretical aspects of different periods, its compositional schools, and genres. The analysis of scientific research has shown that the issues of opera vocal and performing interpretation were covered either indirectly, in the context of studying other issues of the opera, or at the appropriate stage of its historical development. Now contemporary scientific thought faces the task of comprehensively understanding the role of vocal interpretation in the process of creating stage imagery in the opera with the definition of various vocal and interpretive models, taking into account evolutionary processes, national and genre features, the existence of various performing schools and the creativity of individual performers.
\end{abstract}

Keywords: vocal interpretation; opera; performing style; scientific discourse 